Diunggah : Agustus 2020

Diterima : November 2020

Dipublikasi : November 2020

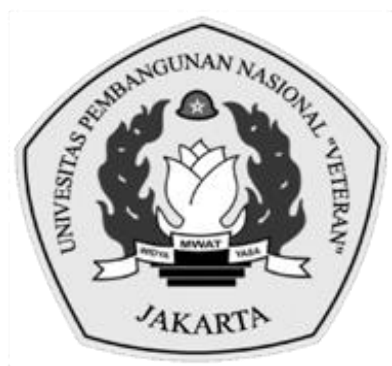

\title{
SISTEM PENGENDALIAN MANAJEMEN DAN PERILAKU ETIS PENGEMUDI TRANSPORTASI ONLINE
}

\author{
Maulina Sadewi ${ }^{1}$, Lely Dahlia ${ }^{2 *}$ \\ 1maulinas2107@gmail.com, 2lelydahlia@trilogi.ac.id \\ Universitas Trilogi, Indonesia \\ *Penulis Korespondensi
}

\begin{abstract}
Abstrak
Tujuan dari penelitian ini adalah untuk mengetahui bagaimana sistem pengendalian manajemen (pengendalian hasil, pengendalian tindakan, pengendalian personel, dan pengendalian budaya) mempengaruhi perilaku etis pengemudi transportasi online. Data dikumpulkan dengan observasi, wawancara, kuesioner, dan dokumentasi. Responden yang digunakan dalam penelitian ini adalah pengemudi transportasi online di DKI Jakarta. Total sampel yang digunakan untuk penelitian ini adalah 100 pengemudi transportasi online di DKI Jakarta. Penelitian ini menggunakan analisis deskriptif dan analisis verifikasi untuk menguji hipotesis dan pemodelan struktural dengan Program SmartPLS Versi 3. Hasil penelitian ini menunjukkan bahwa pengendalian hasil, pengendalian tindakan, pengendalian personel, dan pengendalian budaya yang diterapkan oleh perusahaan tidak memiliki dampak signifikan terhadap perilaku etis pengemudi transportasi online di DKI Jakarta. Hasil dari penelitian ini diharapkan dapat memberikan kontribusi dalam proses pengendalian manajemen dalam rangka membangun perilaku etis pengemudi transportasi online ketika pengemudi melakukan pekerjaan untuk menghasilkan kinerja maksimal untuk mencapai tujuan perusahaan. Selain itu, hasil penelitian ini juga diharapkan menjadi bahan referensi bagi peneliti masa depan di bidang yang sama.
\end{abstract}

Kata Kunci: Pengendalian Hasil; Pengendalian Tindakan; Pengendalian Personel; Pengendalian Budaya; Perilaku Etis

\begin{abstract}
The purpose of this study is to determine how management control systems affect the ethical behavior of online transportation drivers. Data collected by observation, interview, questionnaire, and documentation. The respondents used in this study were online transportation drivers in DKI Jakarta. The total sample used for this study was 100 online transportation drivers in DKI Jakarta. This study uses descriptive analysis and verification analysis to test hypotheses and structural modeling with the SmartPLS Version 3 Program. The result of this research showed that result control, action control, personnel control, and cultural control implemented by the company does not have a significant impact toward ethical behavior of online transportation drivers at DKI Jakarta. The results of this research are expected to give contribution in the management control process in order to establish the ethical behavior of online transportation drivers when the drivers do the job to bring out maximum performance in order to achieve the company's goal. Moreover, the results of this research are also expected to be a reference material for future researchers in the same field.
\end{abstract}

Keywords: Result Control; Action Control; Personnel Control; Cultural Control; Ethical Behavior 


\section{PENDAHULUAN}

Jasa pemesanan transportasi berbasis online sudah tidak asing lagi untuk warga Ibukota Jakarta. Jasa pemesanan transportasi berbasis online hadir sebagai salah satu solusi yang sangat memudahkan kehidupan banyak masyarakat. Jasa pemesanan layanan berbasis online ini hadir dalam bentuk suatu aplikasi dimana layanan yang disediakan tidak hanya transportasi melainkan juga terdapat layanan antar makanan, antar barang, hingga pembayaran. Begitu banyak kemudahan yang diberikan hanya melalui suatu aplikasi yang dapat diakses pada smartphone masyarakat, seperti masyarakat dapat memesan transportasi secara online pada aplikasi di smartphone untuk dijemput di lokasi dimana ia berada hingga diantar sampai lokasi yang dituju. Nilai tambah yang dirasakan para masyarakat selain kemudahan dalam mendapatkan transportasi cepat melainkan harga yang dipasang juga relatif terjangkau dibandingkan menggunakan transportasi konvensional.

Selain itu berkat munculnya perusahaan pemesanan transportasi berbasis online dalam bentuk aplikasi ini cukup berkontribusi mengurangi angka pengangguran. Seperti yang dikutip dari Detik.com bahwa Kecuk Suhariyanto selaku Kepala Badan Pusat Statistik pada bulan Agustus tahun 2016 tingkat pengangguran terbuka mencapai 7,03 juta orang, jumlah ini turun 530.000 orang dibandingkan periode yang sama tahun lalu yang dimana hal ini terjadi berkat maraknya ojek online di beberapa kota-kota besar. Sehingga dengan adanya jasa pemesanan transportasi berbasis online ini semakin meningkatkan kesejahteraan masyarakat yang menjadi pengemudi transportasi online tersebut. Seperti yang dikutip dari Liputan6.com pada tahun 2017 bahwa 84\% warga lebih memilih menggunakan transportasi online karena alasan murah. Alhasil, para masyarakat yang menjadi pengemudi transportasi online dapat menghasilkan pendapatan yang lebih lebih.

Namun, semakin banyaknya jumlah masyarakat yang beralih menjadi pengemudi transportasi online ternyata menimbulkan beberapa tekanan tersendiri bagi beberapa pengemudi yang berakibat mereka mengabaikan tindakan-tindakan yang sesuai dengan etika yang berlaku hanya untuk memenuhi tujuan pribadi atau dapat disebut dengan perilaku tidak etis. Seperti menurut Arens (2012), orang tersebut secara sengaja bertindak tidak etis untuk keuntungan sendiri. Menurut Griffin dan J. Ebert (2015) perilaku etis adalah perilaku yang sesuai dengan norma-norma sosial yang diterima secara umum sehubungan dengan tindakan-tindakan yang bermanfaat atau yang membahayakan. Perilaku etis dalam suatu perusahaan merupakan prioritas yang perlu diperhatikan karena apabila sumber daya manusia dalam suatu perusahaan memiliki perilaku etis maka akan mendukung pencapaian tujuan perusahaan. Suatu perilaku tidak etis dapat muncul dari adanya ketidakpuasan dari hasil yang diperoleh.

Tidak lama ini karena begitu banyaknya jumlah pengemudi transportasi online, beberapa pengemudi yang merasakan tekanan persaingan semakin tinggi melakukan tindakan yang tidak sesuai dengan etika dan norma yang berlaku yaitu melakukan kecurangan dengan orderan fiktif maupun fake GPS. Hal ini terjadi karena dengan semakin banyaknya pengemudi yang bermunculan namun tidak 
sebanding dengan pelanggan yang ada. Kecurangan orderan atau orderan fiktif merupakan salah satu dari suatu tindakan yang tidak sesuai dengan etika dan norma yang berlaku yang dilakukan pengemudi transportasi online dengan bantuan alat lain agar mendapatkan penumpang dan seolah-olah mengantarnya namun kenyataanya para pengemudi tidak mengantar siapapun.

Seperti yang dikutip pada bulan Februari tahun 2018 dari Kompas.com, bahwa ditemukan setidaknya 10 pengemudi ojek online maupun taksi online yang melakukan kecurangan orderan atau orderan fiktif dengan menggunakan aplikasi yang disebut "tuyul" karena pengemudi transportasi online seolah-olah mendapatkan penumpang, lalu mengantar sampai ke tempat tujuan padahal nyatanya pengemudi transportasi online itu tidak mengantarkan penumpang melainkan hanya duduk di tempat. Mekanisme dari aplikasi tuyul ini yaitu, para pengemudi menggunakan fake GPS untuk menentukan lokasi awal, setelah itu ponsel dimodifikasi dengan "tuyul" itu untuk membuat seolah-olah pengemudi benar-benar melayani penumpang. Selain itu ponsel yang dimiliki oleh mitra ojek online tersebut ternyata berjumlah 170 ponsel. Hal itu bertujuan untuk mengelabui perusahaan. Sehingga dari kejadian seperti ini mereka yang melakukan kecurangan orderan mendapatkan bonus banyak namun merugikan perusahaan karena mereka hanya "duduk manis" tetapi seolah-olah melayani pelanggan tetapi bonus dan upah tetap ditransfer perusahaan.

Kejadian orderan fiktif maupun penggunaan fake GPS yang dilakukan oleh beberapa para pengemudi ini merupakan suatu perilaku yang tidak etis di samping merugikan perusahaan, pelanggan, mitra pengemudi lain juga. Dimana perusahaan penyedia layanan berbasis aplikasi merupakan perusahaan yang menyediakan pelayanan maka penting sekali menjaga kepuasan pelanggan untuk mencapai tujuan perusahaan dengan memastikan bahwa para mitra pengemudi berperilaku maupun bertindak etis dalam menjalankan pekerjaannya. Sehingga, dengan begitu penting adanya penerapan sistem pengendalian manajemen yang tepat agar dapat memastikan para pengemudi dapat melakukan pekerjaan sesuai dengan etika dan norma yang berlaku.

Salah satu faktor untuk membangun terciptanya perilaku etis karyawan yaitu dari penerapan sistem pengendalian manajemen. Sistem pengendalian manajemen menurut Merchant dan Stede (2014), merupakan suatu sistem yang diterapkan manajemen untuk mengarahkan perilaku staf agar sesuai dengan tujuan organisasi yang tertuang dalam visi, misi, dan strategi organisasi. Suatu penerapan sistem pengendalian manajemen yang baik diharapkan dapat mengendalikan organisasi serta meminimalkan atau meniadakan tindakantindakan yang tidak sesuai dengan etika yang berlaku dalam perusahaan yang mengganggu pencapaian tujuan perusahaan.

Sistem pengendalian manajemen terdiri dari pengendalian hasil, pengendalian tindakan, pengendalian personel, dan pengendalian budaya. Pengendalian hasil menjadi suatu upaya pencegahan hal-hal di luar ketentuan perusahaan dimana apabila suatu hasil atau tujuan perusahaan dapat dikomunikasikan kepada para karyawan dengan benar dan perusahaan dapat mendorong para karyawan untuk melakukan tindakan yang memberikan hasil sesuai dengan yang diinginkan maka tujuan perusahaan akan lebih mudah tercapai (Merchant dan Stede, 2014). Lalu, pengendalian tindakan merupakan salah satu 
pengendalian manajemen dalam bentuk paling langsung karena tindakan karyawan menjadi fokus pengendalian dibanding dengan bentuk pengendalian lainnya dimana pengendalian tindakan ini suatu pengendalian yang diambil untuk memastikan bahwa karyawan bertindak sesuai dengan keinginan perusahaan dan tidak melakukan hal-hal yang melanggar ketentuan perusahaan (Merchant dan Stede, 2014). Apabila, suatu pengendalian tindakan dalam penerapannya tidak optimal maka dapat berpotensi memunculkan dampak-dampak yang tidak diinginkan (Merchant dan Stede, 2014).

Pengendalian personel yaitu bentuk pengendalian manajemen yang berusaha membangun kecenderungan alami dari masing-masing karyawan untuk memotivasi diri mereka sendiri agar masing-masing karyawan secara mandiri dapat melaksanakan tugas yang diinginkan perusahaan dengan hasil yang memuaskan sehingga menghasilkan realisasi kepuasan tersendiri pada diri karyawan (Merchant dan Stede, 2014). Terakhir yaitu pengendalian budaya, suatu pengendalian yang diciptakan guna mendorong karyawan untuk melakukan tindakan sesuai dengan norma perilaku perusahaan yang berlaku dan mempengaruhi perilaku satu karyawan dan karyawan lainnya (Merchant dan Stede, 2014). Jadi, apabila masing-masing dari pengendalian manajemen ini diterapkan dengan baik maka dapat membantu terciptanya perilaku etis atau dengan kata lain sebagai sistem yang dapat mencegah perilaku tidak etis yang tidak sesuai dengan tujuan perusahaan seperti kecurangan yang muncul dari kepentingan pribadi karena tidak memiliki kesamaan tujuan dengan perusahaan.

Penelitian ini mengacu pada penelitian yang dilakukan oleh Palomino dan Martinez (2011) terkait dengan variabel pengendalian personel yaitu memberikan hasil bahwa pelatihan etika memiliki hubungan positif dengan niat perilaku etis karyawan atau ethical behavior intention; Arifiyani (2012) terkait dengan variabel pengendalian hasil yaitu memberikan hasil bahwa kompensasi berpengaruh terhadap perilaku etis karyawan; Wulandari (2016) terkait dengan variabel pengendalian hasil yaitu memberikan hasil bahwa kompensasi tidak berpengaruh signifikan terhadap perilaku etis karyawan; Muntadhiroh (2018) terkait dengan variabel pengendalian hasil yaitu memberikan hasil bahwa kompensasi berpengaruh positif dan signifikan terhadap perilaku etis karyawan; Setiawan (2013) terkait dengan variabel pengendalian budaya yaitu memberikan hasil bahwa budaya etis berpengaruh positif terhadap perilaku etis; Datrini dkk (2018) terkait dengan variabel pengendalian budaya yaitu memberikan hasil bahwa etika budaya organisasi memiliki pengaruh positif dan signifikan terhadap perilaku etis.

Motivasi penelitian ini adalah dikarenakan dari seluruh penelitian tersebut masih terdapat adanya perbedaan hasil penelitian, selain itu alasan objek penelitian ini pada perusahaan pemesanan layanan berbasis aplikasi karena perusahaan ini menyediakan layanan sehingga penting sekali memastikan para mitra pengemudi berperilaku maupun bertindak sesuai dengan norma dan etika yang diberlakukan pada saat memberikan pelayanan kepada pelanggan. Maka dari itu, hasil dari penelitian ini diharapkan dapat memberikan hasil yang mendukung atau mungkin memberikan hasil yang berbeda sehingga dapat mengembangkan penelitian sejenis kedepannya. Selain itu, hasil penelitian ini diharapkan dapat memberikan kontribusi dalam proses pengendalian manajemen dalam rangka membangun terciptanya perilaku etis pengemudi transportasi online dalam 
melaksanakan pekerjaan agar menghasilkan kinerja yang maksimal dalam mencapai tujuan perusahaan. Berdasarkan latar belakang yang telah dijelaskan diatas, maka penelitian ini bertujuan untuk menentukan apakah pengendalian hasil, pengendalian tindakan, pengendalian personel dan pengendalian budaya berpengaruh terhadap perilaku etis pengemudi transportasi online.

\section{TINJAUAN PUSTAKA}

\section{Sistem Pengendalian Manajemen}

Menurut Merchant dan Stede (2014) sistem pengendalian manajemen merupakan suatu sistem yang diterapkan manajemen untuk mengarahkan perilaku staf agar sesuai dengan tujuan organisasi yang tertuang dalam visi, misi, dan strategi organisasi. Apabila strateginya tidak tepat maka sistem pengendalian manajemen harus dapat menjamin bahwa strategi tersebut dapat dimodifikasi. Pentingnya keberadaan sistem pengendalian manajemen dalam suatu perusahaan agar memastikan para anggota organisasi dapat melakukan pekerjaan sesuai dengan etika dan aturan yang berlaku, karena terkadang beberapa anggota organisasi memiliki kepentingan tersendiri yang tidak sejalan dengan tujuan perusahaan.

Sehingga suatu sistem pengendalian diperlukan untuk mencegah atau memperbaiki suatu tindakan yang tidak sesuai dengan tujuan perusahaan. Sistem pengendalian manajemen terdiri dari empat bentuk menurut Merchant dan Stede (2014) yaitu pengendalian hasil, pengendalian tindakan, pengendalian personel dan pengendalian budaya.

\section{Perilaku Etis dan Tidak Etis}

Menurut Griffin dan J. Ebert (2015) perilaku etis perilaku etis adalah perilaku yang sesuai dengan norma-norma sosial yang diterima secara umum sehubungan dengan tindakan-tindakan yang bermanfaat atau yang membahayakan. Sedangkan, perilaku tidak etis menurut Griffin dan J. Ebert (2015) ialah perilaku yang tidak sesuai dengan norma-norma sosial yang diterima secara umum sehubungan dengan tindakan-tindakan yang bermanfaat atau membahayakan. Menurut Pride et al. (2014) terdapat beberapa faktor yang memengaruhi tingkat perilaku etis dalam suatu organisasi yaitu pertama faktor individu, terdapat beberapa faktor individu yang memengaruhi tingkat perilaku etis dalam suatu organisasi (1) pengetahuan individu tentang sebuah isu; (2) nilai-nilai pribadi; (3) tujuan pribadi., faktor sosial dan faktor peluang.

Kedua yaitu faktor sosial, terdapat beberapa faktor sosial yang memengaruhi tingkat perilaku etis dalam suatu organisasi (1) norma-norma budaya; (2) rekan kerja; (3) orang lain yang berpengaruh; (4) penggunaan internet. Ketiga yaitu faktor peluang, adanya peluang mengacu pada sejumlah kebebasan yang diberikan organisasi kepada karyawan untuk berperilaku tidak etis jika ia membuat pilihan itu. Dalam beberapa organisasi, kebijakan dan prosedur tertentu perusahaan mengurangi kesempatan untuk menjadi tidak etis. Kode etik, dengan adanya kode etik dan pemaksaan yang ditempatkan manajemen dalam kode perusahaan merupakan penentu lain adanya peluang. Melalui tingkat 
penegakan kebijakan perusahaan, prosedur, dan kode etik merupakan kekuatan utama yang memengaruhi peluang. Ketika pelanggaran ditangani dengan konsisten dan tegas maka kesempatan untuk menjadi tidak etis dapat berkurang.

\section{Pengendalian Hasil dan Perilaku Etis Pengemudi Transportasi Online}

Pengendalian hasil merupakan salah satu pengendalian manajemen yang menitikberatkan pada hasil yang dicapai para pegawai. Pengendalian hasil digunakan untuk memastikan apakah para pegawai mengerti atau tidak apa yang diinginkan suatu organisasi dan melakukan suatu tindakan yang memberikan hasil memuaskan sesuai dengan tujuan organisasi (Merchant dan Stede, 2014). Menurut Merchant dan Stede (2014) implementasi dari pengendalian hasil melibatkan empat elemen (1) mendefinisikan dimensi-dimensi dari hasil yang diinginkan; (2) mengukur kinerja dari dimensi yang telah dipilih; (3) menentukan target kinerja karyawan pada tiap-tiap ukuran pencapaian; (4) menyediakan imbalan bagi pencapaian target dan mendorong perilaku yang akan membawa pada hasil yang diinginkan.

Dalam hal ini ketika karyawan mengetahui perilaku seperti apa yang diinginkan perusahaan dan mereka mengetahui apa yang harus dilakukan sekaligus didorong dengan pemberian imbalan atau hukuman maka akan mempengaruhi motivasi karyawan untuk melakukan pekerjaan sebaik mungkin dan memberikan hasil yang memuaskan untuk perusahaan (Merchant dan Stede, 2014). Dengan kata lain pengendalian hasil dapat mendorong karyawan maupun mitra pengemudi transportasi online untuk berperilaku sesuai dengan nilai dan norma yang berlaku dalam rangka memperoleh hasil yang diinginkan perusahaan. Sebaliknya, apabila penerapan pengendalian hasil seperti pendefinisian dimensi kerja, pemberian imbalan atau hukuman tidak optimal maka cenderung akan memunculkan potensi kurangnya pengarahan dan kurangnya motivasi karyawan sehingga memicu karyawan maupun mitra pengemudi transportasi online berperilaku tidak sesuai dengan norma dan nilai yang berlaku dalam memperoleh hasil yang diinginkan perusahaan.

Penelitian yang dilakukan oleh (Arifiyani, 2012) kompensasi berpengaruh terhadap perilaku etis karyawan. Penelitian yang dilakukan oleh (Muntadhiroh, 2018) kompensasi berpengaruh positif dan signifikan terhadap perilaku etis karyawan. Sedangkan penelitian yang dilakukan oleh (Wulandari, 2016) memberikan hasil bahwa kompensasi tidak berpengaruh signifikan terhadap perilaku etis karyawan. Berdasarkan kajian teori dan beberapa hasil penelitian diatas, maka peneliti mengajukan hipotesis yaitu:

\section{H1: Pengendalian hasil berpengaruh terhadap perilaku etis pengemudi transportasi online}

\section{Pengendalian Tindakan dan Perilaku Etis Pengemudi Transportasi Online}

Pengendalian tindakan merupakan suatu pengendalian yang digunakan untuk memastikan agar karyawan melakukan atau tidak melakukan tindakan tertentu yang dinilai dapat menguntungkan atau merugikan perusahaan (Merchant dan Stede, 2014). Di dalam pengendalian tindakan menitikberatkan pada pembatasan akses karyawan untuk menghindari tindakan-tindakan yang tidak sesuai dengan keinginan perusahaan. Seperti pembatasan perilaku yang merupakan bagian dari pengendalian tindakan sangat membantu menghilangkan 
masalah motivasional dimana karyawan awalnya mungkin sempat tergoda untuk terlibat dalam perilaku yang tidak diinginkan dapat terhindar agar tidak berbuat demikian (Merchant dan Stede, 2014).

Menurut Merchant dan Stede (2014) pengendalian tindakan memiliki empat bentuk dasar yaitu (1) pembatasan perilaku; (2) penilaian pratindakan; (3) akuntabilitas tindakan; (4) redundansi. Apabila suatu bentuk pengendalian tindakan diterapkan secara optimal dapat membantu karyawan agar berperilaku sesuai dengan keinginan perusahaan atau dengan kata kata lain sesuai dengan norma dan etika yang berlaku. Sebaliknya, apabila suatu pengendalian tindakan dalam penerapannya tidak optimal maka dapat berpotensi memunculkan dampakdampak yang tidak diinginkan (Merchant dan Stede, 2014). Berdasarkan kajian teori dan beberapa hasil penelitian diatas, maka peneliti mengajukan hipotesis yaitu:

\section{H2: Pengendalian tindakan berpengaruh terhadap perilaku etis pengemudi transportasi online}

\section{Pengendalian Personel dan Perilaku Etis Pengemudi Transportasi Online}

Pengendalian personel merupakan suatu pengendalian yang mendorong kesadaran seorang karyawan agar dapat memotivasi diri mereka sendiri untuk bekerja dan memberikan hasil yang terbaik (Merchant dan Stede, 2014). Pengendalian personel memiliki beberapa tujuan. Pertama, membantu karyawan untuk memahami apa yang diinginkan perusahaan. Kedua, membantu memastikan tiap karyawan bahwa mereka mempunyai kemampuan yang dibutuhkan untuk melakukan pekerjaan dengan baik. Ketiga, yaitu dengan adanya pengendalian personel para karyawan akan terlibat dengan self-monitoring. Self-monitoring terbilang efektif karena mayoritas orang memiliki hati nurani yang membimbing mereka untuk melakukan hal-hal yang baik dan mampu melahirkan perasaan positif akan rasa hormat kepada diri sendiri dan kepuasan saat mereka melakukan pekerjaan dengan baik serta menyaksikan keberhasilan perusahaan (Merchant dan Stede, 2014).

Menurut Merchant dan Stede (2014) pengendalian personel memiliki beberapa bentuk seperti seleksi dan penempatan, pelatihan, serta desain kerja dan sumber daya yang dibutuhkan. Pelaksanaan program pelatihan etika dianggap sebagai instrumen yang tepat untuk mempromosikan perilaku etis di antara karyawan, yang juga didukung secara empiris dalam literature (Palomino dan Martinez, 2011). Menurut wood et al. (dalam Palomino dan Martinez, 2011) program pelatihan dianggap sebagai instrumen yang baik untuk memperkuat sistem nilai karyawan. Menurut Dolan et al. (dalam Palomino dan Martinez, 2011) jika pelatihan digunakan secara luas dalam konteks bisnis untuk mengatasi kemungkinan kekurangan teknis karyawan dalam hal pengetahuan, kemampuan, sikap, dan bahkan perilaku tidak ada alasan untuk meragukan keampuhannya dalam meningkatkan moralitas perilaku karyawan.

Weber (dalam Palomino dan Martinez, 2011) menjelaskan bahwa pelatihan bahkan jika hanya jangka pendek memiliki dampak positif terhadap etika individu. Penelitian yang dilakukan oleh (Palomino dan Martinez, 2011) menunjukkan bahwa pelatihan etika memiliki hubungan positif dengan niat perilaku etis karyawan atau ethical behavior intention. Penerapan pengendalian personel ini 
bertujuan untuk membantu dan memastikan bahwa setiap mitra pengemudi transportasi online memiliki kemampuan untuk melakukan pekerjaan dengan sebaik mungkin serta membangun kecenderungan mitra pengemudi transportasi online untuk memilih perilaku yang baik atau sesuai dengan etika yang berlaku berdasarkan hati nurani yang dimiliki. Berdasarkan kajian teori dan beberapa hasil penelitian diatas, maka peneliti mengajukan hipotesis yaitu:

H3: Pengendalian personel berpengaruh terhadap perilaku etis pengemudi transportasi online

\section{Pengendalian Budaya dan Perilaku Etis Pengemudi Transportasi Online}

Pengendalian budaya didesain untuk mendukung pemantauan bersama, sebuah tekanan kuat dari suatu kelompok terhadap individu yang menyimpang dari norma dan nilai kelompok (Merchant dan Stede, 2014). Penerapan norma di dalam perusahaan menjadi suatu faktor penting untuk meningkatkan perilaku baik karyawan dengan karyawan lainnya dan berperan untuk mencegah perilaku yang tidak selaras dengan norma perusahaan. Dalam hal ini, budaya perusahaan yang kuat dan fungsional memengaruhi karyawan untuk bekerja sama dalam model yang sinergis. Menurut Merchant dan Stede (2014) budaya perusahaan dapat dibentuk dengan berbagai cara, baik melalui kata maupun contoh. Terdapat lima bentuk pengendalian budaya yang dapat diterapkan yaitu (1) kode etik; (2) imbalan kelompok; (3) transfer antarperusahaan; (4) pengaturan fisik; (5) tone at the top.

Dalam Palomino dan Martinez, 2011, faktor budaya organisasi menjadi penting seperti transmisi nilai-nilai etika yang biasanya dicapai melalui penggunaan mekanisme tertentu seperti kode etik, memo, bulletin, program pelatihan, mitos, sejarah dan hotline. Semua mekanisme itu ketika dijalankan secara teratur maka akan membentuk program etika yang fungsi utamanya adalah untuk mempromosikan kesadaran akan masalah etika di antara karyawan untuk meningkatkan etika di tempat kerja. Menurut Schein (dalam Palomino dan Martinez, 2011) budaya organisasi adalah mekanisme kunci yang berpengaruh dalam mentransmisikan nilai kepada karyawan dan dalam memengaruhi perilaku organisasi sehari-hari.

Penelitian yang dilakukan oleh (Setiawan, 2013) menunjukkan bahwa budaya etis berpengaruh positif terhadap perilaku etis. Penelitian yang dilakukan oleh (Datrini dkk, 2018) menunjukkan bahwa etika budaya organisasi memiliki pengaruh positif dan signifikan terhadap perilaku etis auditor. Penerapan pengendalian budaya oleh perusahaan ini bertujuan untuk membantu mengarahkan dan memengaruhi agar mitra pengemudi transportasi online berperilaku atau bertindak sesuai dengan norma dan etika yang berlaku dalam melaksanakan tanggung jawab sehari-harinya. Berdasarkan kajian teori dan beberapa hasil penelitian diatas, maka peneliti mengajukan hipotesis yaitu:

H4: Pengendalian budaya berpengaruh terhadap perilaku etis pengemudi transportasi online

\section{METODOLOGI PENELITIAN}




\section{Populasi dan Sampel}

Menurut Sugiyono (2010) populasi merupakan wilayah generalisasi yang terdiri atas subyek atau obyek yang memiliki karakter dan kualitas tertentu yang ditetapkan oleh seorang peneliti untuk dipelajari yang kemudian ditarik sebuah kesimpulan. Populasi pada penelitian ini yaitu seluruh pengemudi transportasi online pada salah satu perusahaan teknologi penyedia layanan berbasis aplikasi yang berada di wilayah DKI Jakarta.

Sampel merupakan bagian atau jumlah dan karakteristik yang dimiliki oleh populasi tersebut (Sugiyono, 2010) pengambilan sampel dalam penelitian ini menggunakan teknik Insidental sampling. Insidental sampling merupakan teknik penentuan sampel berdasarkan kebetulan, yaitu siapa saja yang kebetulan terdapat pada waktu penelitian dan cocok sebagai sumber data maka dapat digunakan sebagai sampel (Sugiyono, 2010). Teknik insidental sampling ini digunakan untuk mendapatkan anggota sampel dari populasi pengemudi transportasi online pada salah satu perusahaan teknologi penyedia layanan berbasis aplikasi yang berada di wilayah DKI Jakarta. Penentuan jumlah sampel yang digunakan dalam penelitian ini dilakukan dengan menggunakan analisis Structural Equation Modeling (SEM), dimana rumusnya adalah lima dikali jumlah variabel independen indikator (Ferdinand, 2014). Pada penelitian ini jumlah indikator pada variabel independen adalah 15 maka jumlah minimal yang dibutuhkan adalah 75 sampel (dalam penelitian terdapat 100 orang sampel).

\section{Metode Pengumpulan Data}

Data yang digunakan dalam penelitian ini adalah data primer dan data sekunder. Data primer didapatkan peneliti dengan melakukan tinjauan langsung ke lapangan yaitu melalui pertama observasi, wawancara dan kuesioner. Peneliti melakukan observasi terkait tata letak kantor dan kondisi kantor serta observasi terhadap bentuk sistem pengendalian manajemen yang diterapkan pada beberapa pengemudi transportasi online. Kedua melalui wawancara, menurut Sugiyono (2010) wawancara digunakan sebagai teknik pengumpulan data apabila peneliti ingin melakukan studi pendahuluan untuk menemukan permasalahan yang harus diteliti, dan juga apabila peneliti ingin mengetahui hal-hal dari responden yang lebih mendalam dan jumlah respondennya sedikit atau kecil. Pada penelitian ini yang menjadi narasumber wawancara yaitu salah satu staf perusahaan yang mengetahui profil perusahaan, sistem pengendalian manajemen yang diterapkan perusahaan terhadap para pengemudi transportasi online serta pengemudi transportasi online pada salah satu perusahaan teknologi penyedia layanan berbasis aplikasi terkait pemahaman sistem pengendalian manajemen yang diterapkan perusahaan. Selain itu beberapa konsumen pengguna layanan berbasis aplikasi terkait pandangan terhadap perilaku dalam pelayanan yang diberikan pengemudi transportasi online pada salah satu perusahaan teknologi penyedia layanan berbasis aplikasi. Ketiga data diperoleh melalui kuesioner, menurut Sugiyono (2010) kuesioner merupakan teknik pengumpulan data yang dilakukan dengan cara memberi seperangkat pertanyaan atau pertanyaan tertulis kepada responden untuk dijawab. 
Pada penelitian ini yang menjadi responden yaitu para Pengemudi Transportasi Online pada salah satu perusahaan teknologi penyedia layanan berbasis aplikasi. Alat ukur yang digunakan pada kuesioner dalam penelitian ini yaitu menggunakan Skala Likert. Menurut Sugiyono (2010), Skala Likert digunakan untuk mengukur sikap, pendapat, dan persepsi seseorang atau sekelompok orang tentang fenomena sosial. Dalam penelitian ini, peneliti memodifikasi penilaian kuesioner dengan menggunakan Skala Likert enam poin yang menghilangkan poin netral sehingga terdiri dari "Sangat tidak setuju sekali", "Sangat tidak setuju", "Tidak Setuju", "Setuju", "Sangat setuju", dan "Sangat setuju sekali". Penambahan dua poin "Sangat tidak setuju sekali" dan "Sangat setuju sekali" dilakukan dari yang sebelumnya empat poin saja, agar para responden diharapkan dapat memilih jawaban lebih spesifik. Alasan menghilangkan poin netral karena penggunaan Skala Likert tanpa poin netral menurut Hadi (dalam Hertanto, 2017) untuk menghilangkan kelemahan yang terkandung dalam skala lima tingkat. Data sekunder diperoleh peneliti melalui dokumentasi, dalam penelitian ini pengumpulan data melalui dokumentasi berupa profil perusahaan, jurnal serta dokumen-dokumen lain yang mendukung penelitian ini.

\section{Definisi Variabel Operasional}

Dalam penelitian ini yang menjadi variabel eksogen atau variabel independen adalah pengendalian hasil, pengendalian tindakan, pengendalian personel, dan pengendalian budaya. Variabel endogen atau variabel dependen dalam penelitian ini yaitu perilaku etis.

Pengendalian hasil digunakan untuk memastikan apakah para pegawai mengerti atau tidak apa yang diinginkan suatu organisasi dan melakukan suatu tindakan yang memberikan hasil memuaskan sesuai dengan tujuan organisasi (Merchant dan Stade, 2014). Indikator dari variabel pengendalian hasil adalah menentukan pengetahuan dari hasil yang diinginkan, memengaruhi hasil yang diinginkan, serta mengukur efektivitas dan efisiensi hasil yang dapat dikendalikan.

Pengendalian tindakan merupakan suatu pengendalian dengan pengambilan langkah-langkah tertentu untuk memastikan karyawan bertindak sesuai dengan diinginkan perusahaan dengan membuat tindakan karyawan sendiri sebagai fokus pengendalian (Merchant dan Stede, 2014). Indikator dari variabel pengendalian tindakan adalah pembatasan perilaku, penilaian pratindakan, akuntabilitas tindakan dan redundansi.

Pengendalian personel merupakan suatu pengendalian yang mendorong kesadaran setiap individu karyawan untuk memotivasi diri mereka sendiri (Merchant dan Stade, 2014). Indikator dari variabel pengendalian personel adalah seleksi dan penempatan, pelatihan, serta desain pekerjaan dan persediaan sumber daya yang dibutuhkan.

Pengendalian budaya didesain untuk mendukung pemantauan bersama, sebuah tekanan kuat dari suatu kelompok terhadap individu yang menyimpang dari norma dan nilai kelompok (Merchant dan Stade, 2014). Indikator dari variabel pengendalian budaya adalah kode etik, imbalan kelompok, rotasi karyawan, pengaturan fisik dan tone at the top.

Perilaku etis adalah perilaku yang sesuai dengan norma-norma sosial yang diterima secara umum sehubungan dengan tindakan-tindakan yang bermanfaat 
Sadewi \& Dahlia, Sistem Pengendalian Manajemen...

atau yang membahayakan (Griffin dan J. Ebert, 2015). Indikator dari perilaku etis adalah faktor individu, faktor sosial dan faktor peluang. 


\section{Metode Analisis Data}

\section{Analisis Deskriptif}

Analisis statistik deskriptif adalah statistik yang digunakan untuk menganalisis data dengan cara mendeskripsikan atau menggambarkan data yang telah terkumpul sebagaimana adanya tanpa bermaksud membuat kesimpulan yang berlaku untuk umur atau generalisasi (Sugiyono, 2010). Analisis ini dimaksudkan untuk melihat kecenderungan distribusi frekuensi variabel dan menentukan tingkat ketercapaian responden pada masing-masing variabel. Pengujian bergantung pada jenis data yaitu data nominal, ordinal, interval atau rasio.

\section{Analisis Verifikatif}

Analisis verifikatif yaitu analisis yang digunakan untuk membuktikan dan mencari kebenaran dari hipotesis yang diajukan. Pengujian hipotesis dalam penelitian ini menggunakan metode Partial Least Square (PLS) yang dibantu menggunakan program SmartPLS versi 3.2.8 yang telah dirancang khusus untuk mengestimasi persamaan struktural. Metode ini memiliki keunggulan tersendiri yaitu tidak memerlukan asumsi dan dapat diestimasi dengan jumlah sampel yang relatif kecil. Analisa dalam penelitian ini dilakukan melalui tiga tahap yaitu analisa outer model, analisis inner model, dan pengujian hipotesis.

\section{Analisa Outer Model}

Outer model menunjukkan bagaimana variabel manifest atau observed variable merepresentasi variabel laten untuk diukur (Ghozali, 2015). Dalam penelitian ini pengujian validitas terdiri dari (1) Convergent validity, nilai dari convergent validity dari measurement model dengan indikator reflektif dapat dilihat dari korelasi antara nilai item atau indikator dengan nilai konstruknya. Nilai convergent validity dapat dilihat dari nilai loading factor pada tiap indikator konstruk. Nilai yang diharapkan yaitu di atas 0.70 (Ghozali, 2015). (2) Discriminant validity, nilai dari discriminant validity dapat dilihat pada cross loading factor yang berguna untuk mengetahui apakah konstruk laten dapat memprediksi indikator pada blok yang dituju lebih baik dibandingkan dengan indikator blok lainnya yaitu caranya dengan membandingkan nilai loading pada konstruk yang dituju harus lebih tinggi dibandingkan dengan nilai loading konstruk yang lain (Gozali, 2015). (3) Average variance extracted (AVE), nilai AVE dapat digunakan untuk menilai validitas dari konstruk, dipersyaratkan model dapat dikatakan baik apabila AVE masing-masing konstruk nilainya lebih besar dari 0.50 (Ghozali, 2015).

Pengujian reliabilitas dalam penelitian ini terdiri dari (1) Composite reliability, konstruk yang dinyatakan reliabel jika nilai composite reliability di atas 0.70 (Ghozali, 2015). (2) Cronbach's alpha, digunakan untuk memperkuat uji reliabilitas, dimana konstruk dinyatakan reliabel apabila nilai cronbach alpha diatas 0.70 (Ghozali, 2015).

\section{Analisa Inner Model}

Inner model atau model struktural menunjukkan kekuatan estimasi antar variabel laten atau konstruk atau dengan kata lain analisa inner model dilakukan 
untuk memastikan bahwa model struktural yang dibangun akurat. Analisa inner model dapat lakukan melalui pengujian path coefficient, koefisien determinasi $\left(\mathrm{R}^{2}\right)$, dan predictive relevance $\left(\mathrm{q}^{2}\right)$ (Ghozali, 2015). Nilai R-Square 0.67 dikatakan kuat, 0.33 dikatakan sedang, dan 0.19 dikatakan lemah (Ghozali, 2015). Nilai Predictive relevance $\left(\mathrm{q}^{2}\right) 0.02$ menunjukkan bahwa model lemah, 0.15 menunjukkan bahwa model sedang, dan 0.35 menunjukkan bahwa model kuat (Ghozali, 2015). Pengujian hipotesis dilakukan dengan melihat nilai probabilitas p-value menggunakan alpha 5\% adalah kurang dari 0.05 (Ghozali, 2015).

\section{HASIL DAN PEMBAHASAN}

\section{Analisis Deskriptif}

Berikut analisis deskriptif pada seluruh variabel dalam penelitian ini guna mengetahui frekuensi dan persentase dari tanggapan responden terhadap seluruh variabel dalam penelitian ini. Tabel 1. menunjukkan mengenai tanggapan responden secara keseluruhan terhadap variabel pengendalian hasil.

Tabel 1. Tanggapan Responden terhadap Variabel Pengendalian Hasil

\begin{tabular}{ccc}
\hline Tanggapan & Jumlah & Persentase \\
\hline Tidak Setuju & 140 & $20.00 \%$ \\
\hline Setuju & 560 & $80.00 \%$ \\
\hline Total & 700 & $100.00 \%$ \\
\hline
\end{tabular}

Hasil tersebut menunjukkan bahwa sebanyak $80.00 \%$ responden yang artinya melebihi sebagian jumlah total responden setuju terhadap variabel pengendalian hasil. Maka artinya sebagian besar mitra pengemudi transportasi online merasa bahwa perusahaan dapat mendefinisikan serta mengkomunikasikan hasil yang diharapkan secara baik khususnya dalam memberikan informasi mengenai hasil seperti apa yang diharapkan oleh perusahaan, dan memberikan arahan kepada mitra pengemudi untuk mendorong mitra pengemudi melakukan tindakan yang sesuai dengan standar layanan dalam mencapai hasil yang diinginkan perusahaan. Selanjutnya, tanggapan responden terhadap variabel pengendalian tindakan terlihat pada Tabel 2. menunjukkan bahwa sebesar $(88.80 \%)$ atau lebih dari sebagian jumlah total responden menyatakan kesetujuan.

Artinya sebagian besar mitra pengemudi merasakan bahwa perusahaan dapat memengaruhi mitra pengemudi mengenai perilaku serta tindakan apa yang seharusnya dimiliki dan dilakukan atau tidak dimiliki dan tidak dilakukan dalam melaksanakan tanggung jawab pekerjaannya dalam rangka mencapai tujuan perusahaan. Sehingga perusahaan dapat terus mengawasi perilaku maupun tindakan mitra pengemudi agar perilaku maupun tindakan yang dimiliki dan dilakukan oleh mitra pengemudi dapat memberikan keuntungan bagi perusahaan 
dan meminimalkan perilaku maupun tindakan yang melanggar atau tidak sesuai dengan ketentuan yang menyebabkan dampak kerugian bagi perusahaan.

Tabel 2. Tanggapan Responden terhadap Variabel Pengendalian Tindakan

\begin{tabular}{ccc}
\hline Tanggapan & Jumlah & Persentase \\
\hline Tidak Setuju & 56 & $11.20 \%$ \\
\hline Setuju & 444 & $88.80 \%$ \\
\hline Total & 500 & $100.00 \%$ \\
\hline
\end{tabular}

Sumber: Pengolahan data kuesioner, 2019.

Selanjutnya pada Tabel 3. Menunjukkan tanggapan responden secara keseluruhan terhadap variabel pengendalian personel bahwa sebesar $85.33 \%$ responden menyatakan kesetujuan.

Tabel 3. Tanggapan Responden terhadap Variabel Pengendalian Personel

\begin{tabular}{ccc}
\hline Tanggapan & Jumlah & Persentase \\
\hline Tidak Setuju & 88 & $14.67 \%$ \\
\hline Setuju & 512 & $85.33 \%$ \\
\hline Total & 600 & $100.00 \%$ \\
\hline Sumber: Pengolahan data kuesioner, 2019
\end{tabular}

Artinya menunjukkan sebagian besar mitra pengemudi merasakan bahwa perusahaan melakukan pengendalian personel yang membantu membangun kesadaran setiap individu mitra pengemudi untuk mengendalikan dan memotivasi diri mereka sendiri. Berikut dijabarkan lebih lanjut tanggapan responden terhadap variabel pengendalian personel melalui masing-masing indikator variabel pengendalian personel.

Selanjutnya, tanggapan responden secara keseluruhan terhadap variabel pengendalian budaya pada Tabel 4. menunjukkan bahwa sebesar (85.14\%) responden menyatakan kesetujuan. Artinya sebagian besar mitra pengemudi merasakan bahwa perusahaan melakukan pengendalian budaya untuk menghindari perilaku menyimpang dari mitra pengemudi dan meningkatkan hubungan yang baik diantara mitra pengemudi, serta sebagai upaya melakukan pemantauan bersama.

Tabel 4. Tanggapan Responden terhadap Variabel Pengendalian Budaya

\begin{tabular}{ccc}
\hline Tanggapan & Jumlah & Persentase \\
\hline Tidak Setuju & 104 & $14.86 \%$ \\
\hline Setuju & 596 & $85.14 \%$ \\
\hline Total & 700 & $100.00 \%$ \\
\hline
\end{tabular}

Sumber: Pengolahan data kuesioner, 2019. 
Selanjutnya dapat dilihat dari Tabel 5. yang menunjukkan tanggapan responden secara keseluruhan terhadap variabel perilaku etis sebesar $(77.28 \%)$ responden yang menyatakan kesetujuan. Artinya sebagian besar mitra pengemudi merasakan kesetujuan bahwa terdapat beberapa faktor yang memengaruhi serta mendorong mitra pengemudi untuk berperilaku sesuai norma dan etika yang berlaku dalam menjalankan pekerjaanya. Dalam hal ini, mitra pengemudi menyediakan pemberian layanan sehingga diperlukan kesadaran dari dalam diri untuk dapat berperilaku sesuai etika atau aturan dalam menjalankan pekerjaan. Berikut dijabarkan lebih lanjut tanggapan responden terhadap variabel perilaku etis melalui masing-masing indikator variabel perilaku etis.

Tabel 5. Tanggapan Responden terhadap Variabel Perilaku Etis

\begin{tabular}{ccc}
\hline Tanggapan & Jumlah & Persentase \\
\hline Tidak Setuju & 409 & $22.72 \%$ \\
\hline Setuju & 1,391 & $77.28 \%$ \\
\hline Total & 1,800 & $100.00 \%$ \\
\hline Sumber: Pengolahan data kuesioner, 2019.
\end{tabular}

\section{Analisis Verifikatif}

Teknik pengolahan data yang data dilakukan dengan menggunakan metode Partial least Square (PLS) Versi 3.2.8 dengan indikator refleksif. Tahap-tahap analisis outer model, inner model dan pengujian hipotesis akan disediakan di bawah ini.

\section{Uji Validitas}

\section{Convergent validity}

Convergent validity dengan indikator refleksif dinilai berdasarkan hubungan antara item score yang diestimasi dengan menggunakan SmartPLS versi 3. Nilai convergent validity dapat dilihat dari nilai loading factor pada variabel laten dengan indikator-indikatornya dengan nilai yang diharapkan yaitu di atas 0,70 (Ghozali, 2015). Berikut hasil pengolahan data menggunakan SmartPLS versi 3.2.8 pada Gambar 1. 
Gambar 1. Nilai Loading Factor

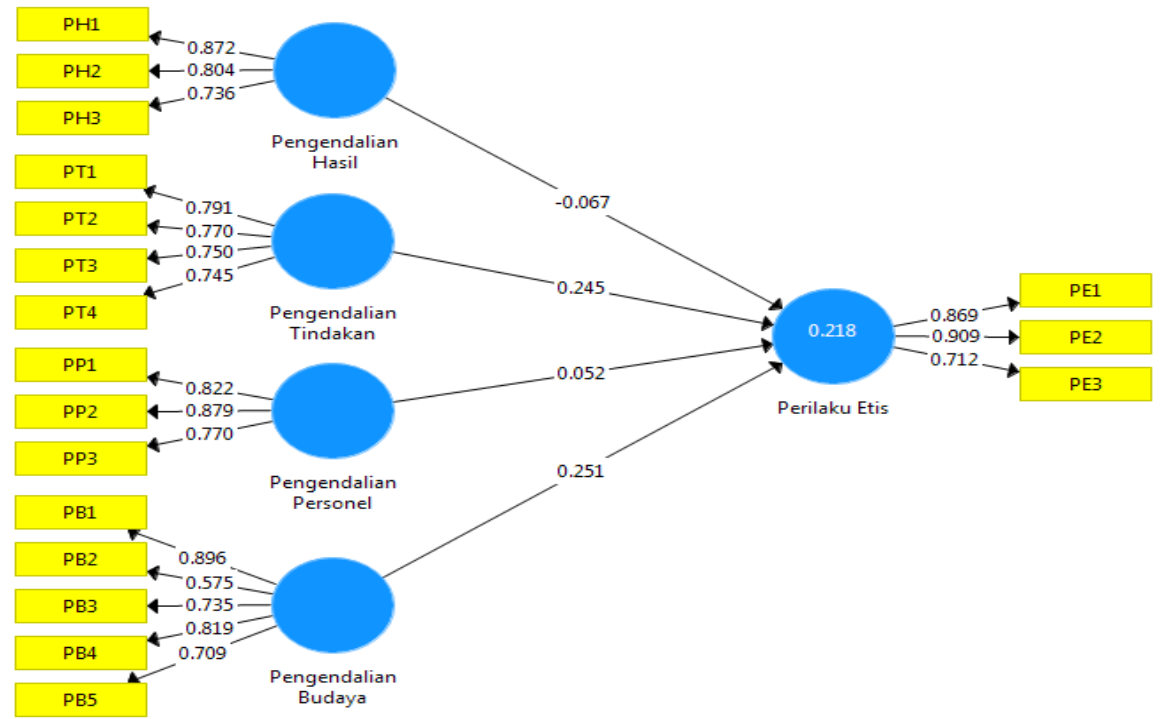

Sumber: Pengolahan data kuesioner dengan SmartPLS versi 3.2.8, 2019.

Dari Gambar 1. menunjukkan bahwa nilai loading factor antara konstruk dengan variabel masih belum memenuhi convergent validity karena masih terdapat indikator yang memiliki nilai loading factor dibawah 0.70 yaitu indikator PB2 yaitu imbalan kelompok dengan nilai loading factor sebesar 0.575 .

Sehingga dari total keseluruhan indikator yaitu berjumlah 18 indikator, terdapat 1 indikator yang masih belum memenuhi batas nilai convergent validity. Maka agar dapat memenuhi kriteria convergent validity, diperlukan modifikasi terhadap model struktur tersebut dengan menghilangkan indikator yang memiliki nilai loading factor dibawah 0.70 (Ghozali, 2015). Jadi, agar dapat memenuhi kriteria convergent validity selanjutnya dilakukan tahap modifikasi model struktur dengan menghilangkan indikator PB2 yang memiliki nilai loading factor 0.575 dibawah kriteria nilai loading factor yaitu 0.70. Indikator PB2 memiliki loading factor yang tidak memenuhi kriteria dikarenakan pernyataan dari indikator tidak dapat mewakili atau sesuai dengan konstruk eksogen yaitu variabel pengendalian budaya yang diterapkan perusahaan karena imbalan kelompok memang tidak diterapkan perusahaan terhadap mitra pengemudi.

Setelah di modifikasi model struktural dengan menghilangkan salah satu indikator maka menghasilkan nilai loading factor seluruh indikator yang memenuhi kriteria nilai loading factor sebesar 0.70. Sehingga indikator-indikator pada penelitian ini dikatakan valid karena telah memenuhi kriteria convergent validity dimana memiliki nilai loading factor diatas 0.70 mulai dari 0.70 hingga 0.91. Hasil loading factor setelah menghilangkan indikator PB2 dapat dilihat pada Gambar 2. 
Gambar 2. Nilai Loading Factor Setelah Pengujian Kedua

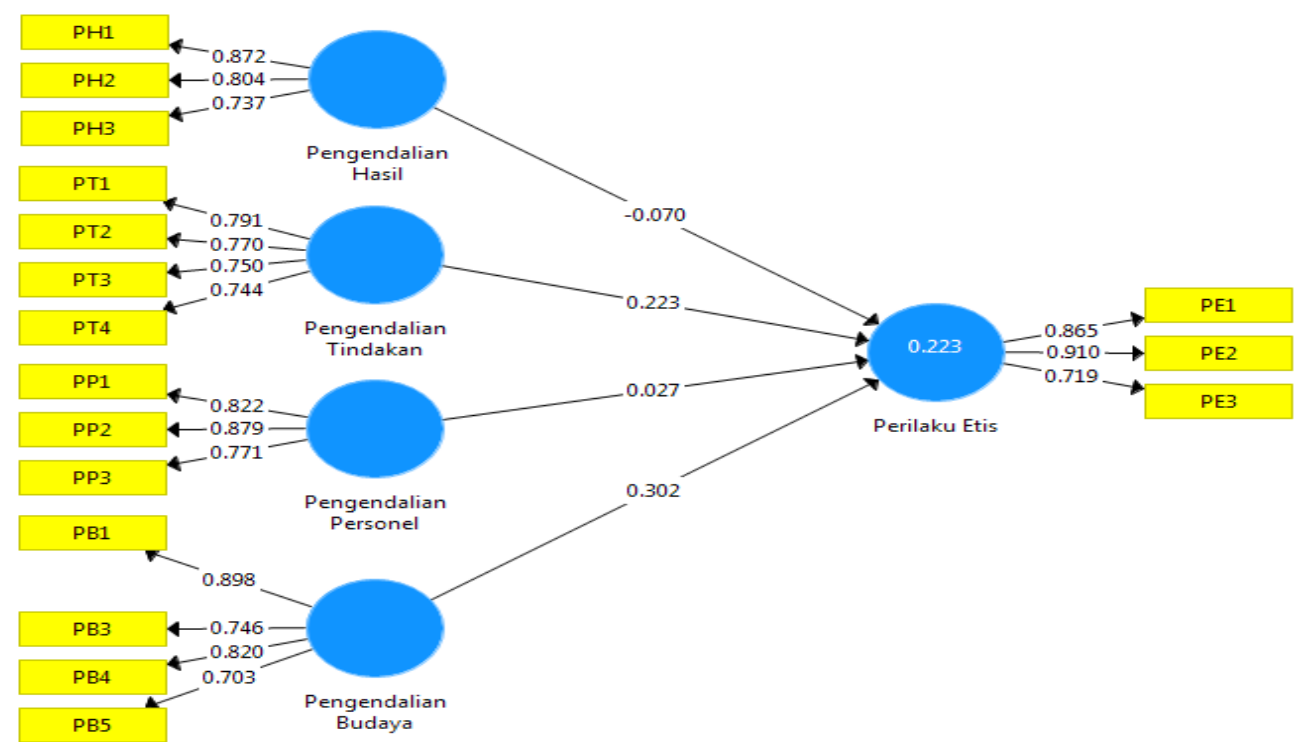

Sumber: Pengolahan data kuesioner dengan SmartPLS versi 3.2.8, 2019.

Discriminant validity dan Average variance extracted (AVE)

Nilai dari discriminant validity dapat dilihat pada cross loading factor yang berguna untuk mengetahui apakah konstruk laten dapat memprediksi indikator pada blok yang dituju lebih baik dibandingkan dengan indikator blok lainnya yaitu caranya dengan membandingkan nilai loading pada konstruksi yang dituju harus lebih tinggi dibandingkan dengan nilai loading konstruk yang lain (Gozali, 2015). Berikut Tabel 4.38 menunjukkan hasil pengujian discriminant validity diperoleh dengan menggunakan SmartPLS versi 3.2.8.

Tabel 6. Cross Loading

\begin{tabular}{lrrrrr}
\hline & $\begin{array}{c}\text { Pengendalian } \\
\text { Budaya }\end{array}$ & $\begin{array}{c}\text { Pengendalian } \\
\text { Hasil }\end{array}$ & $\begin{array}{c}\text { Pengendalian } \\
\text { Personel }\end{array}$ & $\begin{array}{c}\text { Pengendalian } \\
\text { Tindakan }\end{array}$ & $\begin{array}{c}\text { Perilaku } \\
\text { Etis }\end{array}$ \\
\hline PB1 & 0.898 & 0.678 & 0.759 & 0.766 & 0.409 \\
\hline PB3 & 0.746 & 0.456 & 0.622 & 0.628 & 0.321 \\
\hline PB4 & 0.820 & 0.554 & 0.700 & 0.589 & 0.394 \\
\hline PB5 & 0.703 & 0.452 & 0.594 & 0.463 & 0.291 \\
\hline PE1 & 0.402 & 0.262 & 0.408 & 0.418 & 0.865 \\
\hline PE2 & 0.415 & 0.259 & 0.352 & 0.402 & 0.910 \\
\hline PE3 & 0.293 & 0.186 & 0.189 & 0.235 & 0.719 \\
\hline PH1 & 0.665 & 0.872 & 0.661 & 0.615 & 0.282 \\
\hline PH2 & 0.521 & 0.804 & 0.415 & 0.480 & 0.188 \\
\hline PH3 & 0.428 & 0.737 & 0.454 & 0.318 & 0.205 \\
\hline PP1 & 0.700 & 0.561 & 0.822 & 0.669 & 0.263 \\
\hline PP2 & 0.733 & 0.529 & 0.879 & 0.628 & 0.365 \\
\hline
\end{tabular}




\begin{tabular}{lrrrrr}
\hline & $\begin{array}{c}\text { Pengendalian } \\
\text { Budaya }\end{array}$ & $\begin{array}{c}\text { Pengendalian } \\
\text { Hasil }\end{array}$ & $\begin{array}{c}\text { Pengendalian } \\
\text { Personel }\end{array}$ & $\begin{array}{c}\text { Pengendalian } \\
\text { Tindakan }\end{array}$ & $\begin{array}{c}\text { Perilaku } \\
\text { Etis }\end{array}$ \\
\hline PP3 & 0.658 & 0.533 & 0.771 & 0.476 & 0.332 \\
\hline PT1 & 0.591 & 0.411 & 0.579 & 0.791 & 0.366 \\
\hline PT2 & 0.549 & 0.455 & 0.399 & 0.770 & 0.373 \\
\hline PT3 & 0.662 & 0.548 & 0.604 & 0.750 & 0.287 \\
\hline PT4 & 0.592 & 0.437 & 0.632 & 0.744 & 0.280 \\
\hline
\end{tabular}

Sumber: Pengolahan data kuesioner dengan SmartPLS versi 3.2.8, 2019

Berikut ini adalah tabel 7. Yang menunjukkan nilai Average Variance Extracted (AVE)

Tabel 7. Nilai Average Variance Extracted (AVE)

\begin{tabular}{lcccc}
\hline & $\begin{array}{c}\text { Cronbach's } \\
\text { Alpha }\end{array}$ & rho_A & $\begin{array}{c}\text { Composite } \\
\text { Reliability }\end{array}$ & $\begin{array}{c}\text { Average Variance } \\
\text { Extracted (AVE) }\end{array}$ \\
\hline $\begin{array}{l}\text { Pengendalian } \\
\text { Budaya }\end{array}$ & 0.804 & 0.825 & 0.872 & 0.633 \\
\hline $\begin{array}{l}\text { Pengendalian } \\
\text { Hasil }\end{array}$ & 0.732 & 0.770 & 0.847 & 0.650 \\
\hline $\begin{array}{l}\text { Pengendalian } \\
\text { Personel }\end{array}$ & 0.765 & 0.779 & 0.864 & 0.681 \\
\hline $\begin{array}{l}\text { Pengendalian } \\
\text { Tindakan }\end{array}$ & 0.764 & 0.773 & 0.849 & 0.584 \\
\hline Perilaku Etis & 0.783 & 0.825 & 0.873 & 0.697 \\
\hline
\end{tabular}

Sumber: Pengolahan data kuesioner dengan SmartPLS versi 3.2.8, 2019.

Selain melalui nilai cross loading, discriminant validity juga dapat diukur dengan menggunakan nilai Average Variance Extracted (AVE) dengan kriteria apabila nilai Average Variance Extracted (AVE) masing-masing konstruk nilainya lebih besar dari 0.50 (Ghozali, 2015).

Nilai cross loading yang diuji menggunakan SmartPLS versi 3.2.8 pada Tabel 6. berikut menunjukkan bahwa dari seluruh indikator yang berjumlah 17 indikator, jika diukur dari nilai cross loading hasilnya masing-masing indikator memiliki nilai loading pada konstruk yang dituju lebih tinggi dibandingkan dengan nilai loading konstruk yang lain. Serta Tabel 7. menunjukkan nilai Average Variance Extracted (AVE) seluruh konstruk, masing-masing indikator dengan konstruknya melebihi 0.50. Sehingga dapat dikatakan korelasi antara indikator dengan konstruk yang dituju memiliki discriminant validity yang baik. 


\section{Uji Reliabilitas}

\section{Composite reliability}

Composite reliability merupakan uji yang dilakukan untuk menilai apakah masing-masing indikator yang membangun konstruk memiliki reliabilitas atau tidak. Konstruk yang dinyatakan reliabel jika nilai composite reliability di atas 0.70 (Ghozali, 2015). Artinya apabila indikator masing-masing konstruk memiliki nilai sesuai kriteria nilai composite reliability yaitu lebih dari 0.70 maka dapat dikatakan data dari hasil kuesioner yang digunakan memiliki reliabilitas yang tinggi. Hal tersebut dapat dilihat pada Tabel 8. berikut ini.

Tabel 8. Nilai Composite Reliability

\begin{tabular}{lcccc}
\hline & $\begin{array}{c}\text { Cronbach's } \\
\text { Alpha }\end{array}$ & rho_A & $\begin{array}{c}\text { Composite } \\
\text { Reliability }\end{array}$ & $\begin{array}{c}\text { Average Variance } \\
\text { Extracted (AVE) }\end{array}$ \\
\hline $\begin{array}{l}\text { Pengendalian } \\
\text { Budaya }\end{array}$ & 0.804 & 0.825 & 0.872 & 0.633 \\
\hline $\begin{array}{l}\text { Pengendalian } \\
\text { Hasil }\end{array}$ & 0.732 & 0.770 & 0.847 & 0.650 \\
\hline $\begin{array}{l}\text { Pengendalian } \\
\text { Personel }\end{array}$ & 0.765 & 0.779 & 0.864 & 0.681 \\
\hline $\begin{array}{l}\text { Pengendalian } \\
\text { Tindakan }\end{array}$ & 0.764 & 0.773 & 0.849 & 0.584 \\
\hline Perilaku Etis & 0.783 & 0.825 & 0.873 & 0.697 \\
\hline
\end{tabular}

Sumber: Pengolahan data kuesioner dengan SmartPLS versi 3.2.8, 2019.

Tabel 8. menunjukkan bahwa nilai composite reliability masing-masing konstruk dikatakan reliabel karena memenuhi kriteria dari nilai composite reliability yaitu lebih dari 0.70 . Sehingga data yang digunakan dapat dikatakan memiliki reliabilitas yang tinggi.

\section{Cronbach's alpha}

Cronbach's alpha adalah salah satu pengujian selain composite reliability yang digunakan untuk memperkuat uji reliabilitas dari masing-masing konstruk. Konstruk dinyatakan reliabel apabila nilai cronbach's alpha di atas 0.70 (Ghozali, 2015). Nilai Cronbach's alpha pada Tabel 8. menunjukkan bahwa masing-masing konstruk memenuhi kriteria cronbach alpha yaitu memiliki nilai yang melebihi 0.70 maka dapat dikatakan memiliki reliabilitas yang tinggi.

\section{Uji inner model}

Uji inner model atau model struktural menunjukkan kekuatan estimasi antar variabel laten atau konstruk atau dengan kata lain analisa inner model dilakukan untuk memastikan bahwa model struktural yang dibangun akurat. Beberapa uji yang dilakukan dalam pengujian model struktural sebagai berikut: 


\section{Path Coefficient}

Path coefficient yaitu nilai koefisien jalur atau besarnya hubungan atau pengaruh konstruk laten (Ghozali, 2015). Nilai path coefficient diperoleh dengan menggunakan SmartPLS versi 3.2.8 seperti pada Tabel 9. Hasilnya menunjukkan bahwa konstruk pengendalian budaya memiliki pengaruh positif terhadap konstruk perilaku etis dengan nilai sebesar 0.302. Konstruk pengendalian hasil memiliki pengaruh negatif terhadap konstruk perilaku etis dengan nilai sebesar 0.070. Konstruk pengendalian personel memiliki pengaruh atau hubungan positif terhadap konstruk perilaku etis dengan nilai sebesar 0.027. Lalu, konstruk pengendalian tindakan memiliki pengaruh atau hubungan positif terhadap konstruk perilaku etis dengan nilai sebesar 0.223. Sehingga dapat dikatakan bahwa dari seluruh konstruk laten memiliki pengaruh positif kecuali konstruk pengendalian hasil terhadap konstruk perilaku etis.

Tabel 9. Nilai Path Coefficient

\begin{tabular}{lc}
\hline & Perilaku Etis \\
\hline Pengendalian Budaya & 0.302 \\
\hline Pengendalian Hasil & -0.070 \\
\hline Pengendalian Personel & 0.027 \\
\hline Pengendalian Tindakan & 0.223
\end{tabular}

Sumber: Pengolahan data kuesioner dengan SmartPLS versi 3.2.8, 2019.

\section{$R$ Square $\left(R^{2}\right)$}

$\mathrm{R}$ Square $\left(\mathrm{R}^{2}\right)$ yaitu nilai yang digunakan untuk melihat seberapa besar kemampuan variabel bebas dalam menjelaskan varian dari variabel terikatnya. Atau dengan kata lain digunakan untuk menjelaskan pengaruh variabel laten eksogen terhadap variabel laten endogen apakah mempunyai pengaruh yang substantif. Kriteria dari nilai R-Square yaitu 0.67 dikatakan kuat, 0.33 dikatakan sedang, dan 0.19 dikatakan lemah (Ghozali, 2015).

Tabel 10. Nilai R Square $\left(\mathrm{R}^{2}\right)$

\begin{tabular}{ll}
\hline R Square & $\begin{array}{l}\text { R Square } \\
\text { Adjusted }\end{array}$
\end{tabular}

Perilaku Etis $\quad 0.223 \quad 0.190$

Sumber: Pengolahan data kuesioner dengan SmartPLS versi 3.2.8, 2019.

Tabel 10. menunjukkan hasil nilai $\mathrm{R}$ Square $\left(\mathrm{R}^{2}\right)$ untuk konstruk endogen yaitu Perilaku Etis sebesar 0.223 dimana jika disesuaikan dengan kriteria R Square $\left(\mathrm{R}^{2}\right)$ termasuk dalam kategori lemah. Sehingga menunjukkan bahwa hanya sebesar $22.3 \%$ variabel perilaku etis dapat dipengaruhi oleh variabel eksogen yaitu 
pengendalian hasil, pengendalian tindakan, pengendalian personel, dan pengendalian budaya dan sisanya dipengaruhi oleh variabel lain yang tidak diteliti. Sehingga dapat dikatakan bahwa variabel eksogen memiliki pengaruh namun besaran pengaruhnya lemah terhadap variabel endogen karena nilai R Square $\left(\mathrm{R}^{2}\right)$ diatas 0.19 (lemah) tetapi dibawah 0.33 (sedang).

\section{Predictive relevance $\left(q^{2}\right)$}

Pengujian ini dilakukan untuk mengetahui seberapa besar sebuah konstruk eksogen dapat memprediksi relevansi untuk sebuah konstruk endogen. Kriteria dari nilai predictive relevance $\left(\mathrm{q}^{2}\right)$ yaitu 0.02 menunjukkan bahwa model lemah, 0.15 menunjukkan bahwa model sedang, dan 0.35 menunjukkan bahwa model kuat (Ghozali, 2015). Pengujian ini dilakukan dengan menggunakan prosedur blindfolding dalam SmartPLS versi 3.2.8.

Dari Tabel 11. dibawah menunjukkan hasil predictive relevance $\left(\mathrm{q}^{2}\right)$ pada konstruk endogen yaitu perilaku etis sebesar 0.120. Artinya konstruk eksogen yaitu pengendalian hasil, pengendalian tindakan, pengendalian personel dan pengendalian budaya memiliki relevansi prediktif yang lemah karena menurut kriteria diatas 0.02 (lemah) namun masih dibawah 0.15 (sedang) dimana hanya dapat memprediksi relevansi konstruk endogen yaitu perilaku etis sebesar 0.120.

Tabel 11. Hasil Blindfolding Calculation

\begin{tabular}{lrrr}
\hline \multicolumn{1}{c}{ SSO } & \multicolumn{1}{l}{ SSE } & $\mathbf{Q}^{\mathbf{2}}$ (=1-SSE/SSO) \\
\hline Pengendalian Budaya & 400.000 & 400.000 & \\
Pengendalian Hasil & 300.000 & 300.000 & \\
Pengendalian & 300.000 & 300.000 & \\
$\begin{array}{l}\text { Personel } \\
\text { Pengendalian }\end{array}$ & 400.000 & 400.000 & \\
Tindakan & 300.000 & 264.048 & 0.120 \\
Perilaku Etis & & \\
\hline
\end{tabular}

Sumber: Pengolahan data kuesioner dengan SmartPLS versi 3.2.8, 2019.

\section{Pengujian Hipotesis}

Dalam pengujian hipotesis dapat dilakukan dengan melihat output uji hipotesis pada path coefficient yang dilakukan dengan menggunakan prosedur bootstrapping pada SmartPLS versi 3.2.8. Pengujian dengan bootstrapping dapat berguna untuk meminimalkan masalah ketidaknormalan dalam penelitian. Berikut ditunjukkan dalam Tabel 12. mengenai hasil dari pengujian bootstrapping menggunakan SmartPLS versi 3.2.8. 
Tabel 12. Hasil Bootstrapping Calculation

\begin{tabular}{lrrrrr}
\hline & $\begin{array}{c}\text { Original } \\
\text { Sample (0) }\end{array}$ & $\begin{array}{c}\text { Sample } \\
\text { Mean (M) }\end{array}$ & $\begin{array}{c}\text { Standard } \\
\text { Deviation } \\
\text { (STDEV) }\end{array}$ & $\begin{array}{c}\text { T Statistics } \\
(\mid \mathbf{O} / \text { STDEV|) }\end{array}$ & P Values \\
PB -> PE & 0.302 & 0.318 & 0.195 & 1.544 & $\mathbf{0 . 1 2 3}$ \\
PH -> PE & -0.070 & -0.056 & 0.118 & 0.598 & $\mathbf{0 . 5 5 0}$ \\
PP -> PE & 0.027 & 0.029 & 0.168 & 0.160 & $\mathbf{0 . 8 7 3}$ \\
PT -> PE & 0.223 & 0.216 & 0.148 & 1.510 & $\mathbf{0 . 1 3 2}$ \\
\hline
\end{tabular}

Sumber: Pengolahan data kuesioner dengan SmartPLS versi 3.2.8, 2019.

\section{Pengujian hipotesis pengendalian hasil berpengaruh terhadap perilaku etis pengemudi transportasi online}

Dalam Tabel 12. hasil pengujian bootstrapping menunjukkan bahwa hubungan antara variabel pengendalian hasil terhadap variabel perilaku etis pada nilai Original Sample sebesar -0.070. Artinya variabel pengendalian hasil memiliki arah pengaruh yang negatif terhadap variabel perilaku etis. Tetapi memiliki nilai tstatistik sebesar 0.598 dimana nilai tersebut lebih kecil dari t-tabel sebesar 1.96 . Serta nilai $p$-value antara variabel pengendalian hasil terhadap perilaku etis sebesar 0.550 dimana nilai tersebut lebih besar dari kriteria yang ditentukan (kurang dari 0.05). Berdasarkan analisis yang dilakukan menunjukkan hasil bahwa hipotesis satu ditolak, variabel pengendalian hasil tidak berpengaruh signifikan terhadap perilaku etis pengemudi transportasi online. Hal ini sesuai dengan penelitian yang dilakukan oleh (Wulandari, 2016) bahwa kompensasi tidak berpengaruh signifikan terhadap perilaku etis karyawan. Artinya bahwa antara variabel pengendalian hasil yang diterapkan oleh perusahaan dan dirasakan oleh mitra pengemudi memiliki pengaruh tetapi besaran pengaruhnya rendah sehingga tidak dapat memengaruhi secara signifikan perilaku mitra pengemudi untuk sesuai etika atau norma yang berlaku.

Hal ini didukung oleh beberapa faktor, dalam rangka memengaruhi kinerja yang diharapkan dari mitra pengemudi dengan pemberian imbalan berupa bonus yang bertujuan agar mitra pengemudi dapat termotivasi dalam bekerja menjadikan beberapa mitra pengemudi melakukan segala cara untuk mencapai target dan mendapatkan bonus tersebut. Hal ini sesuai dengan tanggapan mitra pengemudi dari hasil kuesioner pada menyatakan bahwa (80.00\%) mitra pengemudi menyatakan perusahaan dapat mendorong motivasi mitra pengemudi untuk bekerja dengan pemberian imbalan. Didukung dengan tanggapan mitra pengemudi pada Lampiran 5. pernyataan nomor 5 bahwa (55.00\%) mitra pengemudi menyetujui melakukan orderan fiktif demi mencapai target pendapatan sedangkan yang menyatakan tidak setuju hanya (45.00\%). Jadi, penerapan pengendalian hasil yang dilakukan perusahaan dengan pemberian imbalan berupa bonus ternyata menjadikan mitra pengemudi melakukan tindakan yang tidak sesuai dengan norma dan etika perusahaan guna memenuhi target poin untuk mendapatkan bonus, sehingga pemberian imbalan sebagai bentuk pengendalian hasil yang diterapkan perusahaan belum dapat memberikan hasil yang sesuai diinginkan oleh perusahaan atau dengan kata lain berlawanan. 


\section{Pengujian hipotesis pengendalian tindakan berpengaruh terhadap perilaku etis pengemudi transportasi online}

Dalam Tabel 12. hasil pengujian bootstrapping menunjukkan bahwa hubungan antara variabel pengendalian tindakan terhadap variabel perilaku etis pada nilai Original Sample sebesar 0.233. Artinya variabel pengendalian tindakan memiliki arah pengaruh yang positif terhadap variabel perilaku etis. Tetapi memiliki nilai t-statistik sebesar 1.510 dimana nilai tersebut lebih kecil dari t-tabel sebesar 1.96. Serta nilai $p$-value antara variabel pengendalian tindakan terhadap perilaku etis sebesar 0.132 dimana nilai tersebut lebih besar dari kriteria yang ditentukan (kurang dari 0.05). Berdasarkan analisis yang dilakukan menunjukkan hasil bahwa hipotesis dua ditolak, variabel pengendalian tindakan tidak berpengaruh secara signifikan terhadap perilaku etis pengemudi transportasi online. Artinya variabel pengendalian tindakan yang diterapkan oleh perusahaan memang memiliki hubungan pengaruh yang positif namun besaran pengaruhnya rendah sehingga tidak memiliki pengaruh secara signifikan terhadap perilaku etis pengemudi transportasi online.

Hal ini didukung dengan beberapa faktor. Dikarenakan masih dalam tahap meningkatkan sistem berdasarkan penuturan pihak perusahaan maka pembatasan perilaku mitra pengemudi untuk tidak berperilaku menyimpang masih kurang optimal karena masih ada celah dimana sistem perusahaan belum bisa $100 \%$ mencegah mitra pengemudi melakukan orderan fiktif. Sesuai dengan hasil wawancara yang dilakukan dengan salah satu mitra pengemudi, bahwa sistem perusahaan masih dikatakan belum optimal dalam mendeteksi kecurangan yang dilakukan sebagian mitra pengemudi. Hal ini juga sesuai dengan tanggapan mitra pengemudi dari hasil kuesioner pada Lampiran 2. bahwa (90.00\%) mitra pengemudi mengetahui bahwa perusahaan memiliki sistem yang dapat membatasi mitra pengemudi untuk berperilaku atau bertindak tidak sesuai norma dan etika yang berlaku. Tetapi didukung dengan tanggapan responden pada hasil kuesioner Lampiran 5. pernyataan nomor 15 bahwa (50.00\%) mitra pengemudi menyatakan setuju jika sistem yang dimiliki perusahaan masih memudahkan mitra pengemudi untuk melakukan order fiktif atau dengan penggunaan fake GPS tetapi $(50.00 \%)$ mitra pengemudi lain merasa sistem yang dimiliki perusahaan tidak memudahkan mitra pengemudi untuk melakukan orderan fiktif maupun penggunaan fake GPS. Sehingga celah peluang yang masih ada pada saat perusahaan dalam proses tahap meningkatkan sistem ini dirasa masih memudahkan sebagian mitra pengemudi untuk melakukan order fiktif maupun penggunaan fake GPS.

Namun dari sisi perusahaan dalam tahap terus meningkatkan sistem sebagian pengemudi lainnya merasa bahwa sistem yang dimiliki perusahaan semakin ketat dan sulit untuk melakukan orderan fiktif atau penggunaan fake GPS. Didukung dengan yang dikutip dari Kumparan.com bahwa pada tahun 2018 dengan adanya pengembangan sistem yang dilakukan perusahaan didukung dengan program \#HapusTuyul, salah satu mitra pengemudi yang melakukan perbuatan curang dengan menggunakan fake GPS secara langsung diberi notifikasi oleh pihak perusahaan agar tidak menggunakannya lagi dan apbila masih menggunakannya maka mitra pengemudi akan kehilangan bonus harian, hal tersebut memang benar-benar membuat jera beberapa mitra pengemudi untuk melakukan tindakan kecurangan. 
Jadi, bentuk pengendalian tindakan yang diterapkan perusahaan dikatakan belum optimal terkait dari segi sistem maupun dari segi akuntabilitas tindakan. Dimana sistem yang dimiliki masih dalam tahap peningkatan yang menjadikan masih adanya celah atau peluang yang memengaruhi sebagian mitra pengemudi berperilaku tidak sesuai dengan norma dan etika yang berlaku seperti melakukan order fiktif dan penggunaan fake GPS. Lalu dari segi akuntabilitas tindakan sebagian besar mitra pengemudi memang telah memahami perilaku atau tindakan seperti apa yang harus dimiliki dan dilakukan dan tidak harus dimiliki dan dilakukan sesuai dengan yang diterapkan oleh perusahaan dalam menjalankan pekerjaan, namun sebagian mitra pengemudi lainnya masih merasa hal tersebut belum dapat memengaruhi agar mitra berperilaku atau bertindak sesuai dengan norma dan etika yang diberlakukan oleh perusahaan dalam menjalankan pekerjaanya karena masih merasa sanksi yang diberikan belum terlalu membuat jera.

\section{Pengujian hipotesis pengendalian personel berpengaruh terhadap perilaku etis pengemudi transportasi online}

Dalam Tabel 12. hasil pengujian bootstrapping menunjukkan bahwa hubungan antara variabel pengendalian personel terhadap variabel perilaku etis pada nilai Original Sample sebesar 0.027. Artinya variabel pengendalian personel memiliki arah pengaruh yang positif terhadap variabel perilaku etis. Tetapi memiliki nilai t-statistik sebesar 0.160 dimana nilai tersebut lebih kecil dari t-tabel sebesar 1.96. Serta nilai $p$-value antara variabel pengendalian personel terhadap perilaku etis sebesar 0.873 dimana nilai tersebut lebih besar dari kriteria yang ditentukan (kurang dari 0.05). Berdasarkan analisis yang dilakukan menunjukkan hasil bahwa hipotesis tiga ditolak, variabel pengendalian personel tidak berpengaruh signifikan terhadap perilaku etis pengemudi transportasi online. Hal ini tidak sesuai dengan penelitian yang dilakukan (Palomino dan Martinez, 2011) yang menghasilkan bahwa pelatihan etika memiliki hubungan positif dengan niat perilaku etis karyawan atau ethical behavior intention. Hal ini dipengaruhi beberapa faktor.

Berdasarkan hasil wawancara dengan pihak perusahaan, pihak mitra pengemudi, dan hasil tanggapan mitra pengemudi melalui kuesioner dapat dikatakan bahwa pengendalian personel yang diterapkan perusahaan memiliki pengaruh namun besaran pengaruhnya rendah maka pengendalian personel yang diterapkan belum dapat memengaruhi secara signifikan agar mitra pengemudi berperilaku sesuai norma dan etika yang berlaku. Hal ini disebabkan dari segi pelatihan sebagai bentuk pengendalian personel yang diadakan perusahaan belum dapat diimplementasikan dengan optimal, dimana mitra pengemudi yang mengikuti pelatihan belum secara keseluruhan. Hal ini didukung dengan tanggapan mitra pengemudi dari hasil kuesioner pada Lampiran 3. pernyataan nomor 3 yang menunjukkan bahwa $(88.00 \%)$ mitra pengemudi selalu mendapatkan dan mengetahui informasi mengenai pelatihan yang diberikan perusahaan. Namun pernyataan nomor 4 hanya sebesar $(81.00 \%)$ mitra pengemudi yang mengikuti pelatihan, tetapi dari (81.00\%) mitra pengemudi yang mengikuti pelatihan pun artinya merasakan bahwa dari hasil pelatihan yang diikuti belum dapat memengaruhi secara signifikan mitra pengemudi untuk 
menentukan atau memilih berperilaku atau bertindak sesuai etika dan norma dalam menjalankan pekerjaan.

Didukung dari hasil wawancara dengan salah satu konsumen pengguna layanan yaitu bernama ibu Ani dimana ia mengalami kecelakaan dengan mitra pengemudi, hal tersebut menandakan bahwa beberapa mitra pengemudi belum dapat mengutamakan keselamatan dan keamanan dalam berkendara pada saat menjalankan pekerjaannya sehingga menimbulkan kekecewaan dan ketidaknyaman konsumen pengguna layanan terhadap pelayanan yang diberikan oleh mitra pengemudi. Serta dari segi penyediaan sumber daya yang dibutuhkan untuk mitra pengemudi, perusahaan kurang memberikan himbauan kepada mitra pengemudi untuk mewajibkan pengambilan seperti masker dan penutup kepala yang berguna menunjang layanan yang diberikan kepada pelanggan sesuai standar layanan yang diberlakukan perusahaan. Didukung dari penuturan mitra pengemudi bahwa untuk masker dan penutup kepala jarang sekali diambil karena tempat pengambilannya cukup jauh dari lokasinya.

\section{Pengujian hipotesis pengendalian budaya berpengaruh terhadap perilaku etis pengemudi transportasi online}

Dalam Tabel 12. hasil pengujian bootstrapping menunjukkan bahwa hubungan antara variabel pengendalian budaya terhadap variabel perilaku etis pada nilai Original Sample sebesar 0.302. Artinya variabel pengendalian budaya memiliki arah pengaruh yang positif terhadap variabel perilaku etis. Tetapi memiliki nilai t-statistik sebesar 1.544 dimana nilai tersebut lebih kecil dari t-tabel sebesar 1.96. Serta nilai $p$-value antara variabel pengendalian budaya terhadap perilaku etis sebesar 0.123 dimana nilai tersebut lebih besar dari kriteria yang ditentukan (kurang dari 0.05). Berdasarkan analisis yang dilakukan menunjukkan hasil bahwa hipotesis empat ditolak, variabel pengendalian budaya tidak berpengaruh signifikan terhadap perilaku etis pengemudi transportasi online. Hal ini tidak sesuai dengan penelitian yang dilakukan oleh (Setiawan, 2013) bahwa budaya etis berpengaruh positif terhadap perilaku etis. Serta penelitian yang dilakukan (Datrini dkk., 2018) bahwa etika budaya organisasi memiliki pengaruh positif dan signifikan terhadap perilaku etis.

Hal ini didukung oleh beberapa faktor. Tanggapan mitra pengemudi dari hasil kuesioner pada Lampiran 4. yang menunjukkan bahwa (86.00\%) mitra pengemudi merasa perilaku staf maupun petinggi kantor cabang operasional sudah melayani dengan cepat dan ramah sesuai dengan budaya yang diterapkan, namun (14.00\%) mitra pengemudi masih merasa bahwa perilaku para staf maupun petinggi kantor dalam melayani mitra pengemudi belum cepat dan ramah sesuai dengan budaya yang diterapkan. Hal tersebut sesuai dengan Lampiran 5. penyataan nomor 9 yang menunjukkan bahwa (76.00\%) mitra pengemudi merasa setiap keluhan dan pendapat selalu didengarkan oleh perusahaan sekaligus diberikan solusi namun masih terdapat (24.00\%) yang merasa bahwa setiap keluhan dan pendapat dari mitra pengemudi belum secara optimal didengarkan dan diberikan solusi. Sesuai dengan hasil wawancara dengan salah satu mitra pengemudi yang menyatakan bahwa, mitra pengemudi merasa bahwa perilaku staf kantor cabang operasional dalam melayani pendapat maupun keluhan mitra pengemudi belum sesuai dengan budaya yang diterapkan. 
Selain itu didukung dari hasil wawancara dengan salah satu konsumen pengguna layanan berbasis aplikasi bernama Peggy yang menyatakan bahwa, mengalami beberapa kejadian yang membuat kecewa dan tidak nyaman akan perilaku beberapa mitra pengemudi dimana ia pernah mendapati salah satu mitra pengemudi mengirimi pesan secara pribadi untuk memintanya agar jika ingin pergi ke suatu tujuan agar dapat menghubunginya, lalu ia juga mendapat kejadian dimana ditelepon oleh salah satu mitra pengemudi yang sehabis mengantarnya dimana ia merasa tindakan maupun perilaku tersebut sangat memberi ketidaknyamanan.

Jadi, bentuk pengendalian yang diterapkan dirasa belum optimal, dimana kode etik yang diterapkan perusahaan dalam bentuk standar layanan belum dapat memengaruhi beberapa mitra pengemudi agar mematuhi dan menerapkannya pada saat menjalankan pekerjaan. Seperti didukung dari hasil wawancara dengan salah satu konsumen pengguna layanan di atas. Selain itu sebagian mitra pengemudi juga masih merasa bahwa perilaku staf kantor cabang operasional belum dapat melayani sebagian keluhan dan pendapat mitra pengemudi dengan baik sesuai dengan budaya perusahaan dengan kata lain sebagian mitra pengemudi merasa staf kantor belum dapat mencerminkan perilaku yang baik sesuai dengan norma dan etika yang diterapkan.

\section{SIMPULAN}

Berdasarkan hasil pembahasan maka dapat disimpulkan bahwa pengendalian hasil, pengendalian tindakan, pengendalian personel dan pengendalian budaya tidak berpengaruh secara signifikan terhadap perilaku etis pengemudi transportasi online pada salah satu perusahaan teknologi penyedia layanan berbasis aplikasi yang berada di wilayah DKI Jakarta.

Hasil penelitian ini dapat menjadi bahan masukan untuk perusahaan penyedia layanan berbasis aplikasi agar lebih mengoptimalkan penerapan sistem pengendalian manajemen yang terdiri dari pengendalian hasil, pengendalian tindakan, pengendalian personel, dan pengendalian budaya untuk membangun perilaku etis pengemudi transportasi online. Dikarenakan hasil dari penelitian ini menunjukkan bahwa pengendalian hasil, pengendalian tindakan, pengendalian personel dan pengendalian budaya yang diterapkan memiliki pengaruh namun besaran pengaruhnya masih rendah sehingga tidak dapat secara signifikan memengaruhi perilaku etis pengemudi transportasi online.

Keterbatasan dalam penelitian ini adalah seluruh hipotesis yang dibangun ditolak, bahwa pengendalian hasil, pengendalian tindakan, pengendalian personel dan pengendalian budaya yang diterapkan perusahaan tidak dapat memengaruhi secara signifikan perilaku etis pengemudi transportasi online. Pemilihan objek penelitian ini yaitu perusahaan teknologi penyedia layanan berbasis aplikasi yang merupakan perusahaan yang masih menjaga kerahasiaan yang sangat ketat sehingga menjadikan masih terbatasnya hasil wawancara dengan narasumber dari perusahaan. Selain itu pemilihan sampel penelitian ini yaitu pengemudi transportasi online yang berada di wilayah DKI Jakarta, dimana karena keterbatasan waktu dan pengetahuan terdapat sebagian mitra pengemudi yang 
kurang membaca dengan teliti setiap pernyataan pada kuesioner. Saran untuk penelitian selanjutnya adalah mempertimbangkan variabel yang tidak berpengaruh bisa tidak diuji atau diuji kembali, selain itu perlunya mempertimbangkan jumlah sisi sampel, dan penelitian selanjutnya perlu mengevaluasi indikator yang ditanyakan pada kuesioner agar responden lebih mudah memahami isi dari pernyataan pada kuesioner yang peneliti berikan.

\section{DAFTAR PUSTAKA}

Arifiyani, H. A. 2012. "Pengaruh Pengendalian Intern, Kepatuhan dan Kompensasi Manajemen Terhadap Perilaku Etis Karyawan (Studi Kasus PT. ADI SATRIA ABADI Yogyakarta)". Jurnal Nominal Volume. 1, No. 1, 2012, 5-21.

Arens, A., Randal, J. E., dan Mark, S. B. 2012. Jasa Audit dan Assurance: Pendekatan Terpadu, Jilid I. Jakarta: Penerbit Salemba Empat.

Chandra, A. A., 2016. Ojek Online Kurangi Pengangguran di Indonesia. https://inet.detik.com/cyberlife/d-3339287/ojek-online-kurangipengangguran-di-indonesia.

Ebert, R. J., Dan Griffin, R. W. 2015. Business Essentials (Tenth Edition). Essex, England: Pearson Education Limited.

Fauwzi, M. G. H. 2011. Analisis Pengaruh Keefektifan Pengendalian Internal, Persepsi Kesesuaian Kompensasi, Moralitas Manajemen Terhadap Perilaku Tidak Etis Dan Kecenderungan Kecurangan Akuntansi. Program Sarjana Fakultas Ekonomi UNDIP: Skripsi tidak diterbitkan.

Ferdinand, A. 2014. Metode Penelitian Manajemen (edisi 5). Semarang: Seri Pustaka Kunci 12.

Ghozali, I., dan Latan, H. (2013). Partial Least Square: Konsep, Teknik dan Aplikasi Menggunakan Program SmartPLS 3.0 (edisi Kedua). Badan Penerbit Universitas Diponegoro.

Hadi, Sutrisno. 1991. Analisis Butir untuk Instrumen Angket, Tes, dan Skala Nilai. Yogyakarta: FP UGM.

Hertanto, E. 2017. PERBEDAAN SKALA LIKERT LIMA SKALA DENGAN MODIFIKASI SKALA LIKERT EMPAT SKALA. http://www.academia.edu/34548201/PERBEDAAN_SKALA_LIKERT_LIMA_ SKALA_DENGAN_MODIFIKASI_SKALA_LIKERT_EMPAT_SKALA.

Hussein, A. S. 2015. Penelitian Bisnis dan Manajemen Menggunakan Partial Least Square (PLS) dengan SmartPLS 3.0. Program studi manajemen Universitas Brawijaya. https://www.google.com/url?sa=t\&rct=j\&q=\&esrc=s\&source=web\&cd=1\& cad=rja\&uact=8\&ved=2ahUKEwjM9sLoxJHhAhXjmuYKHQBQDpEQFjAAegQ IBhAC\&url=https\%3A\%2F\%2Fwww.researchgate.net\%2Ffile.PostFileLoad er.html\%3Fid\%3D5786f4c94048544b3332e123\%26assetKey\%3DAS\%3A 383572759334914\%401468462280965\&usg=AOvVaw3M_mCrbAJUloZjpY SfXIRB.

Merchant, K. A. dan Van der Stede, W. 2014. Management Control System (3 rd edition).

Salemba Empat. 
Noor, J. 2012. Metodologi Penelitian. Jakarta: Kencana Prenada Media Group.

Normadewi, L. P. A. P., Riasning, N. P., dan Datrini, L. K. 2018. "Pengaruh Kecerdasan Dan Budaya Etis Organisasi Terhadap Perilaku Etis Auditor Di Provinsi Bali”. Jurnal KRISNA Vol. 9, No. 2, 63-70.

Palomino, P. R. Dan Martinez, R. 2011. "Human resources Management and Ethical Behaviour: Exploring the Role of Training in the Spanish Banking Industry", Ramon Lull Journal of applied ethics 2011 Issue 2, 70-88.

Praditya, I. I. 2017. 84 persen warga pakai transportasi online karena alasan murah. https://www.liputan6.com/bisnis/read/2950137/84-persenwarga-pakai-transportasi-online-karena-alasan-murah.

Pride, W. M., Hughes, R. J., dan Kapoor, J. R. (2014). Pengantar Bisnis. (Alih Bahasa Abdillah, W., Angelica, D) Jakarta: Salemba Empat.

Puspita, S. 2018. Begini Cara Taksi dan Ojek “Online” Buat Order Fiktif. https://megapolitan.kompas.com/read/2018/02/04/08433971/beginicara-taksi-dan-ojek-online-buat-order-fiktif-pakai-tuyul.

Setiawan, A. S. 2013. Pengaruh Budaya Etis, Orientasi Etis Terhadap Perilaku Etis (Studi

Pada Alumni STIE Musi Palembang). https://www.academia.edu/8526759/PENGARUH_BUDAYA_ETIS_ORIENT ASI_ETIS_TERHADAP_PERILAKU_ETIS_Studi_Pada_Alumni_STIE_Musi_Pale mbang.

Sugiyono. 2010. Metode Penelitian Pendidikan Pendekatan Kuantitatif, kualitatif, dan R\&D. Bandung: Alfabeta

Tatang, M. A. 2010. Skala Likert: Penggunaannya dan Analisis Datanya. https://tatangmanguny.wordpress.com/2010/11/01/skala-likertpenggunaan-dan-analisis-datanya/.

Wulandari, E. 2016. Pengaruh Sistem Pengendalian Intern Dan Kompensasi Terhadap

Perilaku Etis Karyawan Pada PT. Pegadaian (PERSERO) Cabang Syariah Palembang. Program Studi Ekonomi Islam UIN Raden Fatah Palembang : Skripsi tidak diterbitkan. 
Sadewi \& Dahlia, Sistem Pengendalian Manajemen...

Halaman ini sengaja dikosongkan

untuk kepentingan penggenapan halaman 